\title{
Investigation of Computational Thinking in the Context of ICT and Mobile Technologies
}

\author{
Didem Alsancak Sırakaya
}

Kırşehir Ahi Evran University

DOI: $10.21585 /$ ijcses.v3i4.73

\begin{abstract}
This research aims to determine the change in students' computational thinking skills according to their ICT and mobile technology experience and frequency of use. The sample of the study, designed with the survey model, consisted of 269 students attending a vocational school of higher education. Data were collected using the Computational Thinking Scale and the Personal Information Form. Descriptive statistics, independent samples t-test and one-way ANOVA were used in data analysis. According to results, it was determined that students' computational thinking skills differs according to their internet experience, mobile device experience, mobile internet experience and period of daily mobile Internet use, while no differences were found based on computer experience, the number of times they checked their mobile devices a day and purpose of mobile technology usage.
\end{abstract}

Keywords: computational thinking, ICT experience, mobile technology experience

\section{Introduction}

The increase in the space that technology occupies in our lives in terms of volume and function brings about the necessity to update the features that individuals should have (Sirakaya, 2019). Today, regardless of age, every individual is expected to have basic computer skills. Kalelioğlu, Gülbahar and Kukul (2016) state that today, all individuals should have some basic computational skills. Drawing attention to a similar topic, Kalelioğlu (2015) and Sáez-López, Román-González and Vázquez-Cano Lopez (2016), emphasize that individuals in 21st century should not only use technology but also produce technology. In this context, computational thinking skills come to the forefront as among the important skills students should acquire. The concept of computational thinking skills which gained popularity in 2006 with the research conducted by Wing, is essentially a concept that has been discussed in the literature for many years. Wing (2006) pointed out that computational thinking is a necessary competence for every individual.

Although it has been discussed for a long time, it can be argued that there is no consensus on the definition of computational thinking (Grover \& Pea, 2013; Demir \& Seferoğlu, 2017). It is seen that similar definitions are produced for the concept of computational thinking. Some of these definitions are based on computer sciences. Korkmaz, Cakır and Özden (2017) and Wing (2008) point out that the concepts and applications that constitute computational thinking are based on the basic concepts of computer science. Using computer science concepts, Wing (2006) defines computational thinking as problem solving, systems design, and human behaviour analysis. Similarly, Sengupta, Kinnebrew, Basu, Biswas and Clark (2013) state that computational thinking utilizes the basic subjects and concepts found in computer sciences. In different definitions, computational thinking is associated with concepts such as problem solving (Lye \& Koh, 2014), algorithmic thinking (Barr and Stephenson, 2011; Lee et al., 2011) and abstraction (Wing, 2008). Kalelioğlu, Gülbahar and Kukul, (2016) identify three most accepted components of computational thinking as abstraction, algorithmic thinking and problem solving. ISTE (International Society for Technology in Education) (2019) examines computational thinking skills under the 
categories of fragmentation, patterning, abstraction and algorithm. Shute et al. (2017) cite skills such as fragmentation, abstraction, generalization, algorithmic design, debugging and iteration along with thinking and acting as computational thinking skills. From a more general perspective, Pulimood, Pearson and Bates (2016) describe the reasoning process in the solution of abstract problems as computational thinking.

For a better understanding of computational thinking and its concepts, the operational definitions are provided along with its conceptual definition. In their operational definition that considers computational thinking as a problem-solving process, ISTE and CSTA (Computer Science Teachers Association) state that computational thinking includes, but not limited to, the following activities (ISTE, 2019):

- Re-formulating problems in order to solve them with computers and other tools.

- Organizing and analyzing data logically.

- Re-presenting data in manners of abstraction, such as models and simulations.

- Automating solutions through algorithmic thinking.

- Identifying, analyzing and implementing possible solutions to ensure the most effective and efficient combination of steps and resources.

- Generalizing and transferring the problem-solving process to a wide range of problems.

In order to understand the concept of computational thinking more clearly, it may be useful to look at the process from the reverse. In this context, it is useful to take the characteristics of individuals who have computational thinking skills as a reference. Accordingly, individuals with computational thinking skills have the following characteristics (Lee et al. 2011; Wing, 2006, 2008, 2011):

- Making problems solvable by using technological tools.

- Organizing and analyzing data logically.

- Making the data abstract.

- Developing solutions through algorithmic thinking.

- Identifying, analyzing and applying possible solutions and resources.

- Adapting the solution to different problems.

Computational thinking a key skill for the 21st century (Pérez-Marín, Hijón-Neira, Bacelo \& Pizarro, 2018), is a necessary skill for every individual just like literacy and basic mathematical skills (Wing, 2014). Educators are researching how to ensure that students acquire computational thinking skill that is regarded to be highly important (Wing, 2006). Many researchers suggest that computational thinking skill should be added to the curriculum in order to ensure students are given an opportunity to acquire computational thinking skills (Juškevičienė \& Dagienè, 2018; Karal et al., 2017; Yadav et al., 2017). As a matter of fact, many countries include computational thinking in their curricula in order to instruct students starting from early ages (Küçük \& Şişman, 2017; Webb et al., 2017; Wong \& Cheung, 2018). It is aimed to improve students' computational thinking skills through activities such as courses, projects and competitions organized as a supplement to the curriculum. However, it is not clear how to acquire and evaluate this skill, since the definition and limits of computational thinking skills are not clear (Pérez-Marín et al., 2018; Werner, Denner, Campe \& Kawamoto, 2012). In addition, the required level is not achieved yet in terms of resources and informed teachers that are needed to ensure this skill is acquired by students (Brackmann et al., 2016; Pérez-Marín et al., 2018). Literature review shows that different methods and tools are used to develop computational thinking skills. Various methods such as computer-free activities (Takaoka, Fukushima, Hirose \& Hasegawa, 2014), block-based programming (Kalelioğlu, 2015; Yünkül et al., 2017; Oluk \& Korkmaz, 2016; Oluk, Korkmaz \& Oluk, 2018), text-based programming (Alsancak-Sirakaya, 2019) and robotic sets (Karaahmetoğlu \& Korkmaz, 2019) are used for the development of computational thinking skills.

Although different tools are used in the development of computational thinking skills, it is remarkable that most of these tools are technological. Technological tools such as computers, mobile devices, programming languages and robotic sets play an important role in the process of acquiring computational skills. Pellas and Peroutseas (2016) state that computer sciences are an important resource in the acquisition of computational thinking skills. Similarly, in their studies, Yıldız Durak and Sarıtepeci (2018) report that experience in using information and communication technologies (ICT) may influence computational thinking skills. Juškevičienė and Dagienè (2018) state that research on the relationship between digital competence and computational thinking is needed. Based on these, this study aims to determine the change in students' computational thinking skills according to their 
experience and frequency of ICT and mobile technology usage. For this purpose, answers to the following sub-problems are be sought:

- Do students' computational thinking skills significantly differ according to their experience in computer and Internet use?

- Do students' computational thinking skills significantly differ according to their experience in using mobile technologies?

- Do students' computational thinking skills significantly differ according to the frequency of their mobile technology use?

- Do students' computational thinking skills significantly differ according to the purpose of using mobile technology?

\section{Method}

\subsection{Research Design}

Screening model was used in the study. Screening model reveals a group's attitudes, beliefs, thoughts, expectations, attitudes, and characteristics (Creswell, 2012). Creswell (2012) defines screening model as "quantitative research processes that researchers apply to a specific sample to define attitude, opinion, behavior or characteristic features related to the universe". Generally, the aim of screening studies conducted with larger sample groups compared to other types of research is to reveal the situation in question as is (Büyüköztürk, Kılıç Çakmak, Akgün, Karadeniz \& Demirel, 2008).

\subsection{Universe and Sample}

The universe of the study consisted of vocational school of higher education students at a state university and the sample is composed of 269 students from a vocational college at the same state university. According to gender, $18.6 \%$ (50) of the participants were female and $81.4 \%$ (219) were male. Of these, $23 \%$ (62) were in their first year and $77 \%$ (207) were in their second year. According to department, $31.6 \%(85)$ were students at Computer Technologies, 48.3\% (130) were studying Construction Technology, 20.1\% (54) attended the Department of Electricity and Energy. Convenient sampling method was used in determining the study group. In the convenient sampling method, the researcher tries to reach the number of samples that is needed by starting with the participants that he/she can reach most easily (Büyüköztürk et al., 2008). Ethical permit document has been obtained from the educational institution that the students are affiliated with.

\subsection{Data Collection and Data Collection Tools}

The process of data collection began with informing participants verbally about the purpose of the study. Then, data were collected from volunteer participants through data collection tools. The data collection tools used in this study are described below:

Computational Thinking Scale: The Computational Thinking Scale developed by Korkmaz, Çakır and Özden (2017) was used to determine the computational thinking skills of the participants. The scale, with a total of 29 items, is collected under 5 factors. The internal consistency coefficient of the whole scale was calculated as 0.822 and the internal consistency coefficients of the factors were stated as follows: Creativity (0.843), Algorithmic thinking (0.869), Cooperativity (0.865), Critical thinking (0.784) and Problem solving (0.727). The reliability analyses of the scale were re-performed with the data collected within the scope of this study. Accordingly, the overall reliability coefficient of the scale was calculated to be 0.869 with the following internal consistency coefficients for the factors: Creativity, 0.855; Algorithmic thinking, 0,913; Cooperativity, 0.77; Critical thinking, 0,818 and Problem solving, 0.817 . Korkmaz, Çakır and Özden (2017) stated that the scale is a valid measurement tool based on the exploratory and confirmatory factor analyses.

Personal Information Form: Personal Information Form prepared by the researchers was used to determine the gender, department, school year, ICT experience, mobile technology experience, frequency of mobile technology usage and purpose of mobile technology use. The form, which was prepared in accordance with the opinions of two subject areas experts, consists of a total of 16 questions. 


\subsection{Data Analysis}

Since there was a small amount of data loss $(1 \%)$ in the responses to the scale items, mean substitution technique was used based on the recommendation of Schumacker and Lomax (2004). Since the sample size was greater than 50, Kolmogorov-Smirnov test (Büyüköztürk, 2007) and Q-Q Plot graphs were used to determine whether the data showed normal distribution or not. As a result of the test, it was found that the normal distribution value was not statistically significant $(\mathrm{p}>.05)$ and the graphical analysis showed that the data showed normal distribution. For this reason, data analysis included descriptive statistics along with parametric tests such as independent samples t-test and one-way ANOVA. Levene test (variance homogeneity of groups) was taken into consideration in determining which groups caused the difference as a result of ANOVA test. Since the variance was homogeneously distributed in all variables (p> .05), LSD test was preferred (Büyüköztürk, 2007).

\section{Results}

\subsection{Findings Related to Computer and Internet Experience}

In order to determine whether students' computational thinking skills changed according to their computer and internet experiences, one-factor analysis of variance was used for independent samples. The test results are given in Table 1.

Table 1. Change of computational thinking skills according to computer and internet experience

\begin{tabular}{|c|c|c|c|c|c|c|c|c|c|c|c|}
\hline & & & $\mathbf{N}$ & $\bar{x}$ & $\mathbf{S}$ & & & & $\mathbf{N}$ & $\bar{x}$ & $\mathbf{S}$ \\
\hline \multirow{7}{*}{ 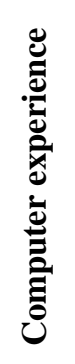 } & 1 & Less & 19 & 87.06 & 21.64 & \multirow{7}{*}{ 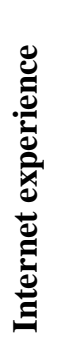 } & 1 & in 1 year & 9 & 94.44 & 17.64 \\
\hline & 2 & Between 1-2 years & 18 & 98.90 & 16.21 & & 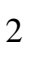 & Between 1-2 years & 28 & 91.54 & 20.51 \\
\hline & 3 & Between 2-3 years & 36 & 100.53 & 15.20 & & $J$ & Between 2-3 years & 43 & 96.01 & 16.99 \\
\hline & 4 & Between 3-4 years & 46 & 98.92 & 18.04 & & 4 & Between 3-4 years & 59 & 97.42 & 16.06 \\
\hline & 5 & Between 4-5 years & 52 & 100.67 & 15.36 & & 5 & Between 4-5 years & 58 & 98.69 & 14.65 \\
\hline & 6 & More than 5 years & 88 & 98.58 & 14.12 & & 6 & More than 5 years & 64 & 102.92 & 15.55 \\
\hline & & Total & 259 & 98.51 & 16.22 & & & Total & 261 & 98.08 & 16.58 \\
\hline
\end{tabular}

\begin{tabular}{|c|c|c|c|c|c|c|c|}
\hline Variable & $\begin{array}{l}\text { Source of } \\
\text { variance }\end{array}$ & Sum of squares & SD & $\begin{array}{l}\text { Mean } \\
\text { square }\end{array}$ & $\mathbf{F}$ & $\mathbf{p}$ & $\begin{array}{l}\text { Significant } \\
\text { difference }\end{array}$ \\
\hline \multirow{3}{*}{$\begin{array}{l}\text { Computer } \\
\text { experience }\end{array}$} & Between groups & 2890.152 & 5 & 578.030 & & & \\
\hline & In-groups & 65017.289 & 253 & 256.985 & 2.249 & .050 & ---- \\
\hline & Total & 67907.441 & 258 & & & & \\
\hline \multirow{3}{*}{$\begin{array}{l}\text { Internet } \\
\text { experience }\end{array}$} & Between groups & 3047.367 & 5 & 609.473 & & & Between 6 and \\
\hline & In-groups & 68446.342 & 255 & 268.417 & 2.271 & .048 & 2,3 \\
\hline & Total & 71493.709 & 260 & & & & \\
\hline
\end{tabular}

According to the Table, it was determined that students' computational thinking mean scores did not show significant differences based on computer experience. $(F(5-253)=2.249 ; \mathrm{p}<=.05)$.

As a result of the analysis, it was determined that internet experience caused a significant difference in computational thinking mean scores $\left(F_{(5-255)}=2.271 ; \mathrm{p}<.05\right)$. According to the LSD test, it was found that students with more than 5 years of internet experience had significantly higher computational thinking scores than those with 1-2 years and 2-3 years of experience.

\subsection{Findings on Mobile Technology Experience}

One-factor analysis of variance for independent samples was used to determine whether students' computational thinking skills changed based on mobile technology experience. The test results are given in Table 2. 
Table 2. Change of computational thinking skills based on mobile technology experience

\begin{tabular}{|c|c|c|c|c|c|c|c|c|c|c|c|c|c|}
\hline & & & & $\mathbf{N}$ & $\bar{x}$ & $\mathbf{S}$ & & & & & $\mathbf{N}$ & $\bar{x}$ & $\mathbf{S}$ \\
\hline \multirow{7}{*}{ 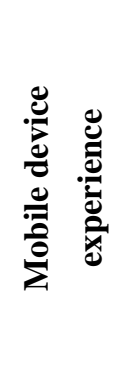 } & \multicolumn{3}{|c|}{1 Less th } & 9 & 89.26 & 22.60 & \multirow{7}{*}{ 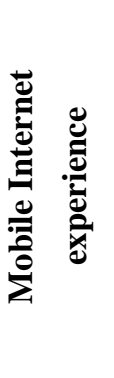 } & 1 & \multicolumn{2}{|c|}{ Less than 1 year } & 12 & 86.88 & 18.57 \\
\hline & \multicolumn{3}{|c|}{2 Between 1-2 years } & 15 & 87.99 & 21.22 & & 2 & \multicolumn{2}{|c|}{ Between 1-2 years } & 24 & 90.48 & 18.98 \\
\hline & \multicolumn{3}{|c|}{3 Between 2-3 years } & 26 & 94.54 & 14.06 & & 3 & \multicolumn{2}{|c|}{ Between 2-3 years } & 40 & 94.95 & 18.28 \\
\hline & \multicolumn{3}{|c|}{4 Between 3-4 years } & 40 & 98.39 & 18.36 & & 4 & \multicolumn{2}{|c|}{ Between 3-4 years } & 50 & 99.48 & 14.05 \\
\hline & \multicolumn{3}{|c|}{5 Between 4-5 years } & 51 & 98.15 & 15.50 & & 5 & \multicolumn{2}{|c|}{ Between 4-5 years } & 69 & 98.05 & 16.00 \\
\hline & \multicolumn{3}{|c|}{6 More than 5 years } & 126 & 100.67 & 15.07 & & 6 & \multicolumn{2}{|c|}{ More than 5 years } & 68 & 103.19 & 14.54 \\
\hline & & Total & & 267 & 98.15 & 16.48 & & & Tota & & 26 & 97.98 & 16.52 \\
\hline \multicolumn{3}{|c|}{ Variable } & $\begin{array}{l}\text { Source of } \\
\text { variance }\end{array}$ & \multicolumn{2}{|c|}{$\begin{array}{l}\text { Sum of } \\
\text { squares }\end{array}$} & SD & \multicolumn{3}{|c|}{ Mean square } & $\mathbf{F}$ & p & \multicolumn{2}{|c|}{$\begin{array}{l}\text { Significant } \\
\text { difference }\end{array}$} \\
\hline \multirow{3}{*}{\multicolumn{3}{|c|}{$\begin{array}{l}\text { Mobile device } \\
\text { experience }\end{array}$}} & Between & \multicolumn{2}{|c|}{3400.874} & 5 & \multicolumn{2}{|c|}{680.175} & & & & \multirow{3}{*}{\multicolumn{2}{|c|}{$\begin{array}{l}\text { Between } 1 \text { and } 6 \\
\text { Between } 2 \text { and } 4 \text {, } \\
5,6\end{array}$}} \\
\hline & & & In-groups & & 13.698 & 261 & 264.0 & & & 2.576 & .027 & & \\
\hline & & & Total & & 314.572 & 266 & & & & & & & \\
\hline \multirow[t]{3}{*}{$\begin{array}{l}\text { Mobile } \\
\text { experieı }\end{array}$} & $\begin{array}{l}\text { Inter } \\
\text { ice }\end{array}$ & rnet & $\begin{array}{l}\text { Between } \\
\text { groups }\end{array}$ & & 4.202 & 5 & 1030. & & & & & \multirow{3}{*}{\multicolumn{2}{|c|}{$\begin{array}{l}\text { Between } 1 \text { and } 4 \text {, } \\
5,6 \\
\text { Between } 2 \text { and } 4 \text {, } \\
5,6\end{array}$}} \\
\hline & & & In-groups & & 104.305 & 257 & \multirow{2}{*}{\multicolumn{3}{|c|}{258.383}} & 3.990 & .002 & & \\
\hline & & & Total & & 58.507 & 262 & & & & & & & \\
\hline
\end{tabular}

When Table 2 was examined, it was found that students' computational thinking skills mean scores differed significantly according to mobile device experience $\left(F_{(5-261)}=2.576 ; p<.05\right)$. The results of the LSD test conducted to determine which groups caused the difference show that computational thinking skills mean scores of students with less than 1 year of mobile device experience were lower compared to those with more than 5 years of experience and computational thinking skills mean scores of students with 1-2 years of experience were significantly lower than those with 3-4 years, 4-5 years and more than 5 years experience in mobile devices.

It was concluded that mobile internet experience caused a significant difference in computational thinking skills scores $\left(F_{(5-257)}=3.990 ; p<.05\right)$. According to the LSD test, it was found that the computational thinking skills mean scores of students with less than 1 year and 1-2 years of mobile internet experience were significantly lower than those with 3-4 years, 4-5 years and more than 5 years experience.

\subsection{Findings Related to Frequency of Mobile Technology Use}

One-factor analysis of variance for independent samples was used in order to determine whether students' computational thinking skills differed based on the frequency of mobile technology use. Table 3 presents the test results. 
Table 3. Changes in computational thinking skills based on frequency of mobile technology use

\begin{tabular}{|c|c|c|c|c|c|c|c|c|c|c|c|c|c|c|}
\hline & & & $\mathbf{N}$ & $\bar{x}$ & & $\mathbf{S}$ & & & & & & $\mathbf{N}$ & $\overline{\bar{X}}$ & $\mathbf{S}$ \\
\hline \multirow{7}{*}{ 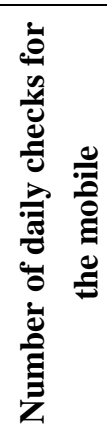 } & & $1-19$ & 69 & \multicolumn{2}{|c|}{93.44} & 19.66 & \multirow{7}{*}{ 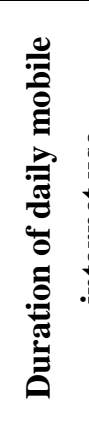 } & & 1 & \multicolumn{2}{|c|}{$<1$ hour } & 38 & 93.52 & 19.44 \\
\hline & & 20- 39 & 48 & \multicolumn{2}{|c|}{102.53} & 13.64 & & & 2 & \multicolumn{2}{|c|}{ 1-2 hours } & 53 & 101.21 & 15.02 \\
\hline & & $40-59$ & 46 & \multicolumn{2}{|c|}{97.85} & 14.72 & & $\notin$ & 3 & \multicolumn{2}{|c|}{ 2-3 hours } & 54 & 98.10 & 15.62 \\
\hline & & $60-79$ & 29 & \multicolumn{2}{|c|}{97.77} & 15.37 & & E & 4 & \multicolumn{2}{|c|}{ 3-4 hours } & 28 & 91.89 & 17.77 \\
\hline & & $80-99$ & 29 & \multicolumn{2}{|c|}{102.21} & 17.70 & & 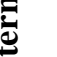 & 5 & \multicolumn{2}{|c|}{ 4-5 hours } & 35 & 101.73 & 17.05 \\
\hline & 6 & $>99$ & 46 & & & 14.22 & & & 6 & \multicolumn{2}{|c|}{$\begin{array}{l}\text { More than } 5 \\
\text { hours }\end{array}$} & 56 & 99.99 & 12.17 \\
\hline & & Total & 267 & & & 16.47 & & & & \multicolumn{2}{|c|}{ Total } & 264 & 98.29 & 16.11 \\
\hline \multicolumn{3}{|c|}{ Variable } & \multicolumn{2}{|c|}{$\begin{array}{l}\text { Source of } \\
\text { variance }\end{array}$} & \multicolumn{2}{|c|}{$\begin{array}{l}\text { Sum of } \\
\text { squares }\end{array}$} & Sd & \multicolumn{3}{|c|}{ Mean square } & $\mathbf{F}$ & p & \multicolumn{2}{|c|}{$\begin{array}{l}\text { Significant } \\
\text { difference }\end{array}$} \\
\hline \multirow{3}{*}{\multicolumn{3}{|c|}{$\begin{array}{l}\text { Number of daily } \\
\text { checks for the } \\
\text { mobile }\end{array}$}} & \multicolumn{2}{|c|}{ Between } & \multicolumn{2}{|c|}{2938.162} & 5 & \multicolumn{2}{|c|}{587.632} & & \multirow{3}{*}{2.214} & \multirow{3}{*}{.053} & & \\
\hline & & & $\begin{array}{l}\text { groups } \\
\text { In-grou }\end{array}$ & & & 4.439 & 261 & & 458 & & & & ----- & \\
\hline & & & Total & & & 2.601 & 266 & & & & & & & \\
\hline \multirow{4}{*}{$\begin{array}{l}\text { Duratio } \\
\text { mobile }\end{array}$} & n c & daily & Betwee & & & 923 & 5 & & 385 & & & & \multirow{4}{*}{\multicolumn{2}{|c|}{$\begin{array}{l}\text { Between } 1 \text { and 2, } 5 \\
\text { Between } 2 \text { and } 4 \\
\text { Between } 4 \text { and 5, } 6\end{array}$}} \\
\hline & int & rnet use & groups & & & & & & & & 6 & 27 & & \\
\hline & & & In-grou & & & 8.895 & 258 & & 864 & & 2.400 & ( & & \\
\hline & & & Total & & & 0.818 & 263 & & & & & & & \\
\hline
\end{tabular}

According to Table 3, it was found that students' computational thinking skills mean scores did not show significant difference based on how many times they checked their mobile devices $(F(5-261)=2.214 ; p>.05)$.

Based on the conducted analyzes, it was determined that duration of daily mobile internet use caused a significant difference in computational thinking skills mean scores $(\mathrm{F}(5-258)=2.406 ; \mathrm{p}<.05)$. According to LSD test results, computational thinking skills of students with less than 1 hour of daily mobile internet use were significantly lower than those with 1-2 hours and 4-5 hours; computational thinking skills of students with 3-4 hours were significantly lower than those with 1-2 hours and computational thinking skills of students with 3-4 hours were significantly lower than those with 4-5 hours and more than 5 hours.

\subsection{Findings Regarding Purpose of Use of Mobile Technology}

Independent samples t-test was applied to determine whether students' computational thinking skills differed based on their purpose for using a mobile technology. Table 4 presented the obtained results. 
Table 4. Change of computational thinking skills based on purpose of using mobile technology

\begin{tabular}{llllllll}
\hline Purpose of Use & At present & $\mathbf{N}$ & $\overline{\mathbf{X}}$ & $\mathbf{S}$ & SD & $\mathbf{t}$ & $\mathbf{p}$ \\
\hline Connecting to social & Yes & 239 & 98.02 & 15.79 & 260 & .768 & .070 \\
networks & No & 23 & 95.29 & 20.72 & & & \\
Playing games & Yes & 146 & 98.20 & 15.86 & 245 & .433 & .387 \\
& No & 101 & 97.27 & 17.53 & & & \\
Keeping up to date with & Yes & 222 & 98.49 & 16.30 & 251 & \multirow{2}{*}{1.309} & .995 \\
current news & No & 31 & 94.37 & 16.90 & & & \\
Doing homework/research & Yes & 221 & 98.20 & 16.68 & 254 & \multirow{2}{*}{1.027} & .224 \\
& No & 35 & 95.14 & 14.01 & & & \\
Listening to music & Yes & 243 & 98.24 & 15.84 & 257 & .410 & .106 \\
\multirow{2}{*}{ Online shopping } & No & 16 & 96.51 & 23.31 & & & \\
\multirow{2}{*}{ Watching videos } & Yes & 144 & 99.16 & 15.64 & 235 & 1.298 & .487 \\
& No & 93 & 96.39 & 16.69 & & & \\
\hline
\end{tabular}

Table 4 shows that while computational thinking skill mean scores of students who used mobile technology to connect to social networks ( $\bar{X}=98.02)$ were higher than the mean score of the students who did not use mobile technology for this purpose ( $\bar{X}=95.29)$, the difference was not significant $\left(t_{(260)}=.768, p>.05\right)$. Similarly, it was concluded that while computational thinking skill mean scores of students who used their mobile technology to play games $(\bar{X}=98.22)$ were higher than the mean scores of students who did not use mobile technology purpose $(\bar{X}=97.27)$, the difference was not significant $(t(245)=.433$, $\mathrm{p}>.05)$.

Although the computational thinking skills mean scores of students who used their mobile technology to follow the current developments $(\bar{X}=98.49)$ were higher than the computational thinking skills mean scores of students who did not use their devices purpose $(\bar{X}=94.37)$, the difference was not significant $\left(t_{(251)}=1.309, p>.05\right)$. It was found that although the computational thinking skills mean scores of students who used their mobile technology for doing homework/research $(\overline{\mathrm{X}}=98.20)$ were higher than the computational thinking skills mean scores of students who did not use their mobile technology for this purpose $(\bar{X}=95.14)$, the difference was not significant $(\mathrm{t}(254)=1.027, \mathrm{p}>.05)$. While the computational thinking skills mean scores of students who used their mobile technology to listen to music was higher $(\overline{\mathrm{X}}=98.24)$ than the computational thinking skills mean scores of students who did not use their devices for this purpose $(\bar{X}=96.51)$, the difference was not significant $\left(t_{(257)}=.410, p>.05\right)$. It was also found that the computational thinking skills mean scores of students who used their mobile technology to do online shopping were higher $(\overline{\mathrm{X}}=99.16)$ than he computational thinking skills mean scores of students who did not use their devices for this purpose $(\bar{X}=96.39)$; the difference was not significant $\left(t_{(235)}=1.298, p>.05\right)$. The findings also show that while the computational thinking skills mean scores of students who used their mobile technology to watch videos were higher $(\bar{X}=98.17)$ than the computational thinking skills mean scores of students who did not use their devices for this purpose $(\bar{X}=96.38)$, the difference was not significant $\left(t_{252}=.445, p>.05\right)$. Evaluation of these results in general demonstrates that students' computational thinking skills did not differ based on the purpose of mobile technology use and that their mean scores were very close to one another.

\section{Results and Discussion}

Based on the results of the analyses, it was determined that students' computational thinking skills did not differ based on computer experience. Arriving at a similar finding, Oluk and Korkmaz (2016) stated that computational thinking skills did not differ according to the duration of daily computer use. Another result obtained in the study demonstrated that internet experience affected computational thinking skills. Accordingly, students with 1-2 years internet experience had significantly lower computational skills than those with more than 5 years experience. Korucu et al. (2017) concluded that middle school students' computational thinking skills did not change based on 
their weekly internet use. Yıldız Durak and Sarıtepeci (2018) concluded that ICT experience did not predict computational thinking skills.

The analyses demonstrated that mobile technology experience differentiated computational thinking skills. Accordingly, students with less mobile device experience and less mobile Internet experience had significantly lower computational thinking skills than those with more experience. This finding can be interpreted to suggest that mobile technology experience can increase computational thinking skills. Reaching a different conclusion, Korucu et al. (2017) stated that those with only 2 years of mobile technology experience had significantly higher computational thinking skills than with longer experience. Differences in the levels of samples in studies may cause variations in the obtained results.

The analyses conducted based on the frequency of mobile technology use concluded that computational thinking skills did not differ according to how many times a person checked his/her mobile device but varied according to the duration of daily mobile Internet use. Accordingly, students who use less mobile Internet daily had significantly lower computational thinking skills than those who used mobile Internet more. According to Korucu et al. (2017), who similarly studied the ability to use mobile devices as a variable, computational thinking skills did not differ. Yildız Durak and Sarıtepeci (2018), who examined the duration of daily internet use of secondary school students, concluded that this variable did not affect computational thinking skills.

The study also aimed to determine whether students' computational thinking skills differed based on their purposes while using their mobile technology. According to the analyses, it was concluded that using mobile technology to connect to social networks, play games, follow the current developments, do homework/research, listen to music, shop and watch videos did not change students' computational thinking skills. While computational thinking skills differed according to mobile device experience and frequency of use, it is a remarkable finding that computational thinking skills did not change based on purpose of use. There are no other studies in the literature that explored these variables. Future studies may consider filling this gap.

This research is limited to 269 vocational school students in terms of participants. One of the limitations of the study is that self-reported instruments were used. Self-reported instruments may not reflect the actual measure as students' perceptions might be differ from their actual levels. Qualitative data collection tools such as observation and interview can be used in future research. In addition, experimental studies examining CT and ICT (mobile technology) can be conducted.

\section{References}

Alsancak-Sırakaya, D. (2019). Programlama öğretiminin bilgi işlemsel düşünme becerisine etkisi. Turkish Journal of Social Research/Turkiye Sosyal Arastirmalar Dergisi, 23(2), 575-590.

Barr, V., \& Stephenson, C. (2011). Bringing computational thinking to K-12: what is Involved and what is the role of the computer science education community? Inroads, 2(1), 48-54.

Brackmann, C., Barone, D., Casali, A., Boucinha, R., \& Muñoz-Hernandez, S. (2016, September). Computational thinking: Panorama of the Americas. In 2016 International symposium on computers in Education (SIIE) (pp. 1-6). IEEE.

Brennan, K., \& Resnick, M. (2012, April). New frameworks for studying and assessing the development of computational thinking. Paper presented at the 2012 annual meeting of the American Educational Research Association, Vancouver, Canada.

Büyüköztürk, Ş. (2007). Sosyal Bilimler İ̧̧in Veri Analizi El Kitabı. Ankara: PegemA Yayıncılık.

Büyüköztürk, Ş., Kılıç Çakmak, E., Akgün, Ö., E., Karadeniz, Ş., \& Demirel, F. (2008). Bilimsel Araştırma Yöntemleri. Ankara: Pegem Akademi.

Creswell, J. W. (2012). Educational research: Planning, conducting and evaluatingquantitative and qualitative research. Boston: Pearson Education.

Demir, G. Ö., \& Seferoğlu, S. S. (2017). Yeni kavramlar, farklı kullanımlar: Bilgi-işlemsel düşünmeyle ilgili bir değerlendirme (Eds: Akkoyunlu, B., Odabaşı, F., \& İşman, A.). In Eğitim teknolojileri okumaları, 801-830.

Grover, S., \& Pea, R. (2013). Computational thinking in K12 a review of the state of the field. Educational Researcher, 42(1), 38-43.

ISTE (2019). Operational definition of computational thinking. Retrieved from https://id.iste.org/docs/ct-documents/computational-thinking-operational-definition-flyer.pdf on 28.11.2019 
Juškevičienė, A., \& Dagienè, V. (2018). Computational thinking relationship with digital competence. Informatics in Education, 17(2), 265-284.

Kalelioglu, F., Gülbahar, Y., \& Kukul, V. (2016). A framework for computational thinking based on a systematic research review. Baltic Journal of Modern Computing, 4(3), 583

Kalelioğlu, F. (2015). A new way of teaching programming skills to K-12 students: Code.org. Computers in Human Behavior, 52, 200-210.

Karaahmetoğlu, K., \& Korkmaz, Ö. (2019). The effect of project-based arduino educational robot applications on students' computational thinking skills and their perception of Basic Stem skill levels. Participatory Educational Research, 6(2), 1-14.

Karal, H., Ş1lbır, G.M., \& Yıldız, M. (2017). STEM eğitiminde bilişimsel düşünme ve kodlamanın rolü. (Ed: Salih Çepni). In Kuramdan Uygulamaya STEM Eğitimi. Ankara: Pegem Akademi, 389-411.

Karasar, N. (2008). Bilimsel araştırma yöntemi. (18. Baskı). Ankara: Nobel Yayın Dağıtım.

Korkmaz, Ö., Çakir, R., \& Özden, M. Y. (2017). A validity and reliability study of the Computational Thinking Scales (CTS). Computers in Human Behavior, 72, 558-569.

Korucu, A.T., Gençtürk, A.T. \& Gündoğdu, M.M. (2017). Examination of the computational thinking skills of students. Journal of Learning and Teaching in Digital Age, 2(1), 11-19.

Küçük, S., \& Şişman, B. (2017). Behavioral patterns of elementary students and teachers in one-to-one robotics instruction. Computers \& Education, 111, 31-43.

Lee, I., Martin, F., Denner, J., Coulter, B., Allan, W., Erickson, J., Malyn-Smith, J., \& Werner, L., 2011. Computational thinking for youth in practice. Acm Inroads, 2(1), 32-37.

Lye, S.Y., \& Koh, J.H.L., 2014. Review on teaching and learning of computational thinking through programming: What is next for K-12?. Computers in Human Behavior, 41, 51-61.

Oluk, A., Korkmaz, Ö., \& Oluk, H.A. (2018). Scratch'ın 5. sınıf öğrencilerinin algoritma geliştirme ve bilgi-işlemsel düşünme becerilerine etkisi. Turkish Journal of Computer and Mathematics Education, 9(1), 54-71.

Oluk, A., \& Korkmaz, Ö. (2016). Comparing students' scratch skills with their computational thinking skills in terms of different variables. Online Submission, 8(11), 1-7.

Pellas, N., \& Peroutseas, E. (2016). Gaming in Second Life via Scratch4SL: Engaging high school students in programming courses. Journal of Educational Computing Research, 54(1), 108-143.

Pérez-Marín, D., Hijón-Neira, R., Bacelo, A., \& Pizarro, C. (2018). Can computational thinking be improved by using a methodology based on metaphors and scratch to teach computer programming to children? Computers in Human Behavior.

Pulimood, S. M., Pearson, K., \& Bates, D. C. (2016, February). A study on the impact of multidisciplinary collaboration on computational thinking. In Proceedings of the 47th ACM technical symposium on computing science education (pp. 30-35). ACM.

Sáez-López, J. M., Román-González, M., \& Vázquez-Cano, E. (2016). Visual programming languages integrated across the curriculum in elementary school: A two years case study using "Scratch" in five schools. Computers \& Education, 97, 129-141.

Schumacker, R.E., \& Lomax, R.G. (2004). Data Entry and Data Editing Issues. In A beginner's guide to structural equation modeling (pp. 13-33). Mahwah, NJ: Lawrence Erlbaum

Sengupta, P., Kinnebrew, J. S., Basu, S., Biswas, G., \& Clark, D. (2013). Integrating computational thinking with K-12 science education using agent-based computation: A theoretical framework. Education and Information Technologies, 18(2), 351-380.

Shute, V. J., Sun, C., \& Asbell-Clarke, J. (2017). Demystifying computational thinking. Educational Research Review, 22, 142-158.

Sırakaya, M. (2019). İlkokul ve ortaokul öğretmenlerinin teknoloji kabul durumları. Inönü Üniversitesi Eğitim Fakültesi Dergisi, 20(2), 578-590. 
Webb, M., Davis, N., Bell, T., Katz, Y. J., Reynolds, N., Chambers, D. P., \& Sysło, M. M. (2017). Computer science in K-12 school curricula of the 21st century: Why, what and when?. Education and Information Technologies, 22(2), 445-468.

Werner, L., Denner, J., Campe, S., \& Kawamoto, D. C. (2012, February). The fairy performance assessment: measuring computational thinking in middle school. In Proceedings of the 43rd ACM technical symposium on Computer Science Education (pp. 215-220). ACM.

Wing, J. M. (2014). Computational thinking benefits society, 40th Anniversary Blog of Social Issues in Computing, 2014

Wing, J. M. (2006). Computational thinking. Communications of the ACM, 49(3), 33-35

Wing, J. M. (2011). Computational thinking. In G. Costagliola, A. Ko, A. Cypher, J. Nichols, C. Scaffidi, C. Kelleher, et al. (Eds.), 2011 IEEE symposium on visual languages and human-centric computing (p. 3).

Wing, J. M., (2008). Computational thinking and thinking about computing. Philosophical Transactions of The Royal Society of London A: Mathematical, Physical And Engineering Sciences, 366(1881), 3717-3725.

Ylldı Durak, H., \& Saritepeci, M. (2018). Analysis of the relation between computational thinking skills and various variables with the structural equation model. Computers \& Education, 116, 191-202.

Yunkül, E., Durak, G., Çankaya, S., \& Misırlı, Z.A. (2017). The effects of Scratch software on students' computational thinking skills. Necatibey Eğitim Fakültesi Fen ve Matematik Eğitimi Dergisi, 11(2), 502-517. 